Корнівська В. О., д.е.н. ДУ «Інститут економіки та прогнозування Наиіональної академії наук України» м. Київ, Украӥна

DOI: https://doi.org/10.30525/978-9934-26-028-5-50

\title{
ФІНАНСОВА ІНКЛЮЗІЯ: ЛОГІКО-ІСТОРИЧНИЙ ЗМІСТ
}

Фінансова інклюзія втілює доступність фінансових послуг, що забезпечується багатством Інтернет-технологій, засобами мобільного зв'язку для віддаленого доступу до будь-якої фінансової операції: від переказу до отримання кредиту та страхування автомобіля. Розповсюдженою у сучасному науковому дискурсі $\epsilon$ думка, що фінансова інклюзія полегшує повсякденну економічну активність ринкових суб'єктів, а також допомагає домогосподарствам та компаніям планувати все - від довгострокових цілей до несподіваних надзвичайних ситуацій. Отже сьогодні 
фінансова інклюзія розглядається частіше у прикладній, абстрактно-актуальній формі, що стосується взаємодії клієнта та фінансової установи 3 приводу ефективного отримання фінансової послуги.

Водночас поєднання функціональної та логіко-історичної методології дослідження надає можливості проаналізувати фінансову інклюзію як історичний феномен, що розвивається від перших операцій кредитування, розрахункових операцій i представляє собою механізм надання/отримання ліквідності для забезпечення операційної активності ринкових суб'єктів, зумовленої їхніми економічними інтересами. Фінансова інклюзія розвивається як механізм надання конкретної послуги, але водночас це механізм включення клієнтів в систему фінансових операцій, у систему комплементарної взаємодії реального сектора економіки та фінансового, яка $є$ базисом розвитку конкретноісторичної домінантної сфери, що, задовольняючи економічні інтереси ринкових суб'єктів, одночасно стимулює економічний розвиток суспільства. На кожному історичному етапі можна виявити ареал максимального впливу і максимального ефекту від комплементарної взаємодії фінансового сектору та реального, отже фінансове залучення завжди отримує конкретно-історичне завдання, що формується у зв'язку із загальними тенденціями, цілями економічного розвитку: у докапіталістичну епоху - це розвиток сфери торгівлі, у капіталістичну епоху - виробництва. У сучасну перехідну епоху капіталістичної транзиції та становлення інформаційно-мережевої економіки - це забезпечення збуту продукції глобальних корпорацій.

У попередніх роботах остання теза була детально обгрунтована [1], у цій роботі наведемо лише базові підходи нашого аналізу. Результатом процесу капіталістичної трансформації та інформаційної революції стало формування гнучких глобальних мереж виробництва та реалізації, що характеризуються швидким оновленням асортименту та якості продукції. Новітні технології як запорука конкурентної перемоги зробили оновлення асортименту та підвищення якості виробленої продукції єдино 
можливим шляхом розвитку глобальних корпорацій. При цьому цикл виробництва значно скоротився, обсяги продукції до реалізації постійно зростали, у цих умовах виникла потреба у специфічній системі реалізації продукції, якою стала мережа, з їі основною ціллю - створенням попиту. Капіталістична економіка постійно наштовхується на проблему реалізації виготовленої продукції, адже попит на неї перебуває поза бажанням та волею капіталіста. Звідси і кризи перевиробництва, якими рясніла капіталістична економіка на ранніх стадіях розвитку.

В умовах інформаційно-мережевої економіки фундаментальна проблема попиту може бути вирішеною через стимулювання штучних споживчих потреб у мережевій системі реалізації продукції, що відповідає за активізацію продажу зростаючих товарних лінійок глобальних корпорацій. При цьому механізми створення попиту стають дедалі більш неринковими та асиметричними. I тут виникає базове протиріччя: розвиток інформаційно-мережевої економіки з самого початку відбувався на тлі зростання проблеми бідності та нерівності у світі. За умов зростання нерівності та невирішених проблем зубожіння, монетизований шляхом зароблених доходів попит не відповідає зростаючим обсягам пропозиції. Монетизація попиту відбувається двома шляхами: зростанням доходів (заробітних плат), або зростанням кредитної складової споживання. В сучасних умовах монетизація попиту все більше залежить від споживчого кредиту. При цьому зростання фінансової інтегрованості домогосподарств - це механізм нейтралізації кризи надвиробництва глобальних корпорацій. Якщо в капіталістичній економіці кредит домінантно потрібний для організації процесів виробництва, то в інформаційно-мережевій економіці зростає його роль стосовно забезпечення реалізації продукції.

Маючи глибинне еволюційне підгрунтя, на сучасному етапі розвитку фінансова інклюзія стимулюється низкою актуальних факторів. По-перше, це зростання конкуренції в середовищі фінансових установ через активізацію цифрового переходу, що стимулює банківські установи до залучення більшого числа 
клієнтів для забезпечення конкурентних переваг. По-друге, це профіцит ліквідності у глобальному фінансовому просторі як результат контркризової політики центральних банків, що стала тенденцією в умовах почастішання кризових явищ у світовій та національних економіках за останні півстоліття. Дані процеси призвели до поступового зниження відсоткових ставок (навіть до укорінення наднизьких та від'ємних в європейській системі фінансово-інституційних координат), що зумовило необхідність переформатування банківських бізнес-моделей з орієнтацією на комісійні доходи та трансакційні операції, які потребують зростання фінансового залучення клієнтів. По-третє, умови цифрового суспільства надають можливості професійної реалізації в Інтернет-середовищі, екосистемах цифрових торгівельних платформ все більшій кількості зацікавлених осіб; для забезпечення цих процесів необхідною $є$ фінансова інклюзія, що починається із відкриття банківського рахунку. По-четверте, фінансова інклюзія в багатьох країнах, що розвиваються, необхідна для забезпечення ефективної політики соціальних трансфертів, так в Індії для отримання фінансової допомоги 3 боку держави, якої потребує практично чверть індійського населення, необхідно бути фінансово інклюзованим та бути включеним у систему біометричної ідентифікації, причому, спочатку ці процеси проходили на добровільній основі, сьогодні - під жорстким державним контролем. По-п'яте, фінансова інклюзія - це не тільки результат агресивної політики банківських установ щодо зростання пропозиції фінансових послуг, це закономірна тенденція зміни клієнтського попиту через трансформації фінансової культури та фінансової поведінки населення, готового до активної співпраці 3 фінансовою установою для забезпечення ефективної споживчої операційної активності. Більше того, сьогодні «цифрова фінансова інклюзія еволюціонує від «витрачати» до «позичати» і, як правило, заповнює прогалину у наданні фінансових послуг у тих країнах, де вони не розповсюджені» [2]. Переважно це бідні країни, у яких умови незадоволеного базового попиту стимулюють споживчу 
активність, яка через низький рівень доходів збільшує кредитну активність населення, що актуалізує низку соціогуманітарних ризиків, зокрема, ризик формування фінансово-орієнтованих моделей поведінки через низький рівень людського розвитку та освіти.

Глибинне логіко-історичне підгрунтя фінансової інклюзії, підкріплене актуальними факторами соціально-економічної та інституційної динаміки, зокрема зростанням невизначеності у глобальному середовищі, призводять до поширення фінансової інклюзії і їі інституційних ризиків.

Головним довгостроковим інституційним ризиком глобальної фінансової інклюзії є погодження на втрату фінансової свободи 3 боку ринкових суб'єктів в умовах зростання невизначеності економічного та суспільного буття та проблем бідності. Падіння доходів, політична, економічна, епідеміологічна невизначеності все частіше породжують у суб'єктів нівелювання віри у свої власні економічні можливості та укорінюють надію на зовнішню допомогу: держави, банку, - яка стає постійно відтворюваним елементом економічного буття без наявності альтернатив можливості завдяки своїм власним доходам забезпечити соціальну усталеність та соціальну мобільність. В умовах рецесії, викликаної епідемією COVID-19, через втрату робочих місць, зростання цін та перебої в послугах, таких як освіта та охорона здоров'я, рівень бідності зростатиме. Саме бідні верства населення потребуватимуть державного трансфертного фінансування, яке в сучасних умовах неможливо без фінансової інклюзії. I саме серед незаможних домогосподарств сьогодні продовжують розвивати мікрокредитування, яке, як показує досвід Індії, може завершуватися не тільки економічним крахом, а життєвою катастрофою. В умовах старої, класичної, традиційної нормальності суспільства працюючих інститутів, стабільних соціальних та економічних зв'язків фінансова інклюзія була лише одним із механізмів фінансової операційної активності, для сучасного суспільства пануючої невизначеності, триваючої кризової біфуркації, інституційного нівелювання - це інваріант. 


\section{Література:}

1. Корнівська В.О. Інститути фінансового посередництва в процесі формування інформаційно-мережевої економіки. Київ. Інститут економіки та прогнозування НАН України, 2018. 436 с.

2. Ratna Sahay, Ulric Eriksson von Allmen, Amina Lahreche, Purva Khera, Sumiko Ogawa, Majid Bazarbash, and Kim Beaton. The Promise of Fintech: Financial Inclusion in the Post COVID-19 Era. International Monetary Fund. 2020. 20/09. 